\title{
医療ビッグデータにおける自発報告データベースの位置づけと利用可能性
}

\author{
酒井隆全
}

\section{Role and Applicability of Spontaneous Reporting Databases in Medical Big Data}

\author{
Takamasa Sakai
}

Drug Informatics, Faculty of Pharmacy, Meijo University; 150 Yagotoyama, Tempaku-ku, Nagoya 468-8503, Japan.

(Received August 26, 2020)

\begin{abstract}
In recent years, a variety of medical information has been digitized, and hence, various medical big data have become available. Spontaneous reporting databases are a part of the medical big data. In Japan, the Pharmaceuticals and Medical Devices Agency has developed the "Japanese Adverse Drug Event Report (JADER) database" which has been available since 2012. Thus, everyone can publish safety signal information based on the results of disproportionality analysis using the spontaneous reporting database. Since the release of JADER, many researchers and healthcare professionals are interested in it, and many reports have been prepared using JADER. Although we tend to focus on the fact that it is a publicly available database with many cases, it also has various limitations such as lack of the denominator information, under-reporting, and reporting biases. Detected signals do not necessarily imply a causal relationship between the drug and adverse event. In the "Guideline on good pharmacovigilance practices (GVP) Module IX by European Medicines Agency”, signal detection is the first step in the signal management process. Signal detection alone does not complete pharmacovigilance activities. It is important to understand that spontaneous reporting databases are not only for researchers but also for those who are considering to apply them to clinical work by referring to research using these databases. In this symposium review, I will discuss the role and applicability of spontaneous reporting databases in medical big data.
\end{abstract}

Key words_ _ signal detection; pharmacovigilance; spontaneous reporting database; data mining

\section{はじめに}

近年，電子機器の性能が発達し，様々な医療情報 が電子媒体で生成・蓄積されつつある。これによ り，従来では取り扱うことのできなかった医療ビッ グデータが利用可能となってきている. ビッグデー 夕の定義や医療分野においてビッグデータとして取 り扱われる範囲は様々な意見があるが，樋之津は 「医療ビッグデータ」に用いるデータソースの 1 つ として自発報告データベースを挙げている. 1)ま た，日本の自発報告データベースである Japanese Adverse Drug Event Report database (JADER) に ついて,「ビッグデータの 3 つの V」²) 観点から鑑 みると，1）デー夕量（Volume）: 現時点で約 60 万 件，2）速度（Velocity）：月に 1 度の更新，3）多

名城大学薬学部医薬品情報学研究室（广468-8503 名古 屋市天白区八事山 150)

e-mail: tksakai@meijo-u.ac.jp

本総説は, 日本薬学会第 140 年会シンポジウム S45 で 発表した内容を中心に記述したものである.
様性（Variety）：多種多様な患者における情報が報 告され得る，と一定の水準ではこれらの特性を持つ データとも考えられる，そこで，本稿では自発報告 データベースを医療ビッグデータの 1 つと捉えるこ ととし，その特性を踏まえた医療ビッグデータにお ける位置づけを考察していきたい.

\section{自発報告之医薬品安全性監視}

医薬品が承認されるまでに行われる治験には，一 般的に5Toos と呼ばれる限界があり, ${ }^{3)}$ 市販後に多 くの患者に対して様々な状況下で医薬品が使用され て，初めて発見される副作用も数多く存在する。 そ のため, 市販後の医薬品安全性監視が必要であり, 医療現場で生じた副作用の自発報告は市販後の医薬 品安全性監視における重要な情報源の 1 つである. 自発報告の収集は様々な国や機関で行われており， 収集した自発報告を集積してデータベースが構築さ れている（Table 1)。中には，日本や米国のように そのデータセットを公表している場合もある。 日本 では 2012 年に医薬品医療機器総合機構（Phar- 
Table 1. International and National Spontaneous Reporting Databases

\begin{tabular}{|c|c|c|}
\hline & Database Name & $\begin{array}{l}\text { Name of the } \\
\text { Regulatory Authority }\end{array}$ \\
\hline $\begin{array}{l}\text { World Health } \\
\text { Organization }\end{array}$ & VigiBase & $\begin{array}{l}\text { The Uppsala } \\
\text { Monitoring Centre }\end{array}$ \\
\hline Japan & $\begin{array}{l}\text { Japanese Adverse } \\
\text { Drug Event } \\
\text { Report database }\end{array}$ & $\begin{array}{l}\text { Pharmaceuticals and } \\
\text { Medical Devices } \\
\text { Agency/Ministry of } \\
\text { Health, Labour and } \\
\text { Welfare }\end{array}$ \\
\hline $\begin{array}{l}\text { The United } \\
\text { States }\end{array}$ & $\begin{array}{l}\text { FDA Adverse } \\
\text { Event Reporting } \\
\text { System database }\end{array}$ & $\begin{array}{l}\text { United States Food } \\
\text { and Drug Adminis- } \\
\text { tration }\end{array}$ \\
\hline European Union & EudraVigilance & $\begin{array}{l}\text { European Medicines } \\
\text { Agency }\end{array}$ \\
\hline Canada & Canada Vigilance & Health Canada \\
\hline The Netherlands & Lareb database & $\begin{array}{l}\text { Netherlands Pharma- } \\
\text { covigilance Centre } \\
\text { Lareb }\end{array}$ \\
\hline $\begin{array}{l}\text { The United } \\
\text { Kingdom }\end{array}$ & $\begin{array}{l}\text { "Yellow Card" } \\
\text { database }\end{array}$ & $\begin{array}{l}\text { Medicines and } \\
\text { Healthcare products } \\
\text { Regulatory Agency }\end{array}$ \\
\hline
\end{tabular}

FDA: Food and Drug Administration. Cited and modified in part: Council for International Organizations of Medical Sciences Working Group VIII, "Practical aspects of signal detection in pharmacovigilance: Report of the CIOMS Working Group VIII," World Health Organization, Geneva, 2010.

maceuticals and Medical Devices Agency; PMDA) がデータセットを公開したことにより，誰でも自発 報告データベースを用いた解析結果に基づく安全性 情報の発信が可能となり，多くの医療従事者や研究 者の注目を集めている。

自発報告データベースを用いた分析の主な目的 は，シグナルを検出することである．シグナルと は，「単一あるいは複数の情報源（観察及び実験） から得られた情報であり，それらは，介入と事象の 関係，あるいは有害もしくは有用な事象の中での新 たな潜在的な因果関係や，すでに知られていた関係 での新たな側面を示すものであり，検証するに足り る十分な可能性があると判断されたもの」と定義さ れる. ${ }^{4)}$ 自発報告からのシグナル検出は伝統的なシ グナル検出と統計的なシグナル検出に大別されてい る. 伝統的なシグナル検出として従来行われてきた のは，質的アプローチとして個別症例あるいは集積 症例に対する医学的なレビュー等，定量的アプロー チとして症例数や報告割合の算出等である。これに 対して, 統計的なシグナル検出は, 1990 年代以降 に自発報告データベースが大規模となってきたこと から統計学的手法が取り入れられることで実施され るようになったものである. ${ }^{5,6)}$ 医療ビッグデータと
しての自発報告データベースの活用について議論さ れる際には，不均衡分析 (Disproportionality Analysis）による統計学的なシグナル検出を指し示して いることが多い。不均衡分析の原理や各シグナル指 標に関する詳細な説明については成書6)に委ねる が，統計学的なシグナル検出手法を用いることで, データベースに集積された情報に対して迅速かつ網 羅的な分析を行うことが可能である。このことか ら, 統計的なシグナル検出は, 統計学的データマイ ニングとも表現されることがある.データマイニン グとは，「巨大なデータセットやデータベースから

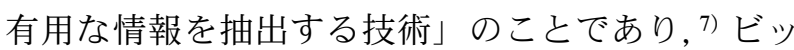
グデータという鉱山から金脈を採掘する（mining） こととして例えられる。

実際，統計的なシグナル検出を行うと検出基準を 満たす多くの医薬品と有害事象の組合せが発見され る。その中には，シグナルが検出された後にシグナ ル検証や評価を経て添付文書や医薬品リスク管理計 画の改訂が行われるきっかけとなるものもある。欧 州医薬品庁 (European Medicines Agency; EMA) では，年次報告書においてシグナル検出結果を公表 しており，2019 年は EMA がレビューした 1806 シ グナルのうち，35 のシグナルが最終的に製品情報 の改訂につながったと報告されている. ${ }^{8)}$ 日本にお いても，2019 年 5 月にナトリウム・グルコース共 輸送体 2 阻害剂の添付文書にフル二工壊疽に関する 記載が追加となった際に，「改訂の理由及び調査の 結果」の欄には世界保健機関 (WHO) の VigiBase ${ }^{\circledR}$ における不均衡分析結果が記載されており, ${ }^{9)}$ 自発 報告データベースの解析結果が活用されて規制措置 が行われた事例が存在している。このように，医療 現場で医療従事者が副作用を疑つた事例が集積さ れ，それらの事例を分析して得られた知見は医薬品 安全性監視に活用されている.

一方で，検出されたシグナルのすべてが添付文書 改訂や緊急安全性情報の発出などをもたらすものと は限らない.PMDAの「データマイニング手法の 導入に関する検討結果報告書」では，シグナル検出 の妥当性の評価を実施した結果，検討条件や手法間 で異なるものの感度は概ね約 20-60\%程度であり， 特異度とトレードオフの関係にあると示されてい る. ${ }^{10)}$ また，自発報告データベースを用いた統計的 なシグナル検出に関する種々の限界は既に指摘され 


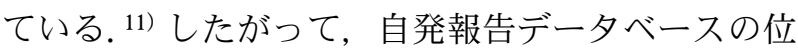
置づけを正しく把握し適切に活用することが重要と なる.

\section{自発報告データベースの位置づけ}

われわれは，自発報告データベースの有する症例 数に目を向けがちであるが，医療ビッグデー夕にお ける位置づけを的確にとらえるためにはその成り立 ちに由来する特性についても考えるべきである，自 発報告データベースには基本的になんらかの有害事 象が発生した事例のみが集積されるため，副作用の 発現率等を算出するためのいわゆる「分母情報」を 有していない。また，実際に発生した有害事象がか ならずしもすべて報告されているわけではなく，自 発報告された症例はその一部に過ぎないという過少 報告の可能性がある。このほか，日本における市販 後調査制度による影響として，使用成績調査や市販 直後調査による報告増加なども影響し得る。このよ うに，自発報告データベースにはその成り立ちに由 来する様々な限界がある。不均衡分析においてあら かじめ設定した閾值を超えたことで見い出された関 連性が，かならずしも薬剤と有害事象の因果関係を 意味するものではない，EMAの “Guideline on good pharmacovigilance practices (GVP) Module IX”において，シグナル管理のプロセスとしてシ グナル検出の後は検証，優先順位付け，評価，措置 の勧告と続くものとされている.5) シグナル検出 は，医薬品リスク管理のプロセスの起点となるもの であり，仮説生成がその主な役割であることから， 通常，検出されたシグナルは更なる検討を経る必要 がある，以上を踏まえると，例えば自発報告デー夕 ベースから検出されたシグナルを研究題材として, 仮説の強化・検証を可能とするような研究デザイン による更なる疫学研究を計画することは，自発報告 データベースの位置づけを考慮した研究の 1 つのあ り方であろう。

\section{JADERを用いた研究におけるチェックリストの} 作成

ここまでに述べたように，自発報告データベース を用いたシグナル検出には考慮すべき種々の限界点 が存在する．わが国では JADER が公開されてから 盛んに自発報告データベースを用いた研究が発表さ れていたものの，その限界点に留意していない報告 が散見されることを問題視する声があがっていた.
そこで，筆者らはJADER を用いた研究を行う際の 留意点を端的に示す必要があると考え，「JADER を用いたデータマイニング（主に不均衡分析による シグナル検出）の研究発表の際に留意すべきチェッ

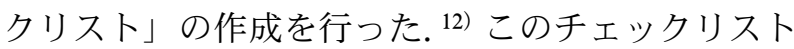
は，国際医学団体協議会（Council for International Organizations of Medical Science; CIOMS) ワーキ ンググループによる報告書である，「ファーマコビ ジランスにおけるシグナル検出の実践」6)を基に素 案を作成し，JADERを用いた研究を用いたパイ ロットテスト，エキスパートレビューを経て作成し たものである，チェックリストは，すべての研究で 行っていることが望ましい（必須項目）12 項目と, かならずしも行っている必要はないが考慮すること が望ましい（考慮項目） 5 項目の計 17 項目からな る．例えば，シグナル検出の位置づけに関する内容 としては，「検討課題に関する現状を記述し，検討 課題が未知の医薬品-有害事象の関連性である旨が 示されていること．仮説生成がシグナル検出の本来 の主たる目的である，既知の医薬品-有害事象の関 連性における新たな側面を検討するものや既知の医 薬品一有害事象の関連性を題材にデータマイニング の手法について検討したものである場合は，その旨 が明記されていること」という項目を設けた。本チ エックリストの活用が，JADER を用いた研究の質 的向上の一助となることを期待している.

\section{JADER を用いた研究の実態調査}

さらに，筆者らは前述のチェックリストを用いて， JADER を用いたシグナル検出により医薬品と有害 事象の関連性を検討した学術論文 39 件を調査対象

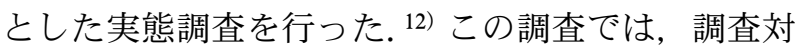
象の学術論文において, チェックリスト中の必須項 目 12 項目を満たすか否かの判定を行った。この 際，判定が困難な場合には 2 名の研究者による協議 のうえで決定した。

実態調査の結果，12 項目のすべてを満たしたの は 1 件 $(2.6 \%)$ のみであり，中には必須項目の半 数以下しか満たさなかった学術論文も 3 件 $(7.7 \%)$ 存在した. 特に, エビデンスの質の高い研究により 既知である医薬品と有害事象の関連性についてシグ ナル検出を行っているものや，用いられた Medical Dictionary for Regulatory Activities (MedDRA) に 関する記載がないもの，不適切なバージョンの 
MedDRA が用いられているものが多数認められ た。このほか，チェックリストの中には，遵守され ないことで医療現場における意思決定に誤った影響 を与える可能性が高いと考えられるチェック項目と して,「リスクの定量化を行っていないこと．通常， 自発報告データから見出されるのは仮説である」や 「複数の医薬品の不均衡計算値 (Reporting Odds Ratio；ROR など）について，計算值の大きさのみ によって単純な比較を行っていないこと」などがあ る. 本研究の結果では, これらのチェック項目の充 足率は比較的高かったものの, 調査対象となった学 術論文の中にもこれらのチェック項目を満たさない ものが存在していた。このことからも，自発報告 データベースを研究に用いる者だけでなく，それら を用いた研究成果を参照し臨床業務への応用を考え る者にも適切な理解が求められていると言える.

\section{まとめ}

自発報告は従前より医薬品安全性監視に活用され てきた重要な情報源である．統計学的シグナル検出 によって迅速かつ網羅的な検討が可能であるが，同 時にその限界点にも留意する必要がある. シグナル 検出は，医薬品リスク管理のプロセスの起点となる ものであり，仮説生成がその主な役割となる，自発 報告データベースを扱う研究者だけでなく，研究成 果を参照する側にとつてもこれらを理解しておくこ とが重要である.

謝辞本総説執筆の機会を頂いた，本シンポジ ウムのオーガナイザーである百 賢二先生，武隈 洋先生に感謝申し上げます。

利益相反＼cjkstart開示すべき利益相反はない.

\section{REFERENCES}

1) Hinotsu S., J. Jpn. Soc. Hosp. Pharm., 56, 27-32 (2020) .

2) IBM. "IBM Data Engine for Hadoop and
Spark.": 〈http: // www.redbooks.ibm.com / redbooks/pdfs/sg248359.pdf $\rangle$, cited 14 July, 2020.

3) Rogers A. S., Drug Intell. Clin. Pharm., 21, 915-920 (1987).

4) Hauben M., Aronson J. K., Drug Saf., 32, 99110 (2009).

5) Kokan A., Kawaguchi G., Jpn. J. Pharmacoepidemiol., 25, 28-38 (2020).

6) Council for International Organizations of Medical Sciences Working Group VIII, “Practical Aspects of Signal Detection in Pharmacovigilance: Report of the CIOMS Working Group VIII,"’ World Health Organization, Geneva, 2010.

7) "Data Mining Applications in Engineering and Medicine," ed. by Karahoca A., IntechOpen, London, 2012, p. 3.

8) European Medicines Agency. "Annual Report 2019: The European Medicines Agency's contribution to science, medicines and health in 2019."': 〈https: / / www.ema.europa.eu / en / documents / annual-report / 2019-annualreport-european-medicines-agency _ en.pdf $\rangle$, cited 14 July, 2020.

9) Pharmaceuticals and Medical Devices Agency. "Summary of investigation results, Sodiumglucose co-transporter 2 (SGLT2), Inhibitors and combination products containing SGLT2 inhibitors.": 〈https://www.pmda.go.jp/files /000229446.pdf $\rangle$, cited 14 July, 2020.

10) Pharmaceuticals and Medical Devices Agency. "Data Mining Shuho no Donyu ni kansuru Kento Kekka Houkokusho (heisei 19 nen 3 gatsu )": 〈https: // www.pmda.go.jp / files / 000148312.pdf $\rangle$, cited 14 July, 2020.

11) Urushihara H., Jpn. J. Drug Inform., 21, 135-141 (2020).

12) Sakai T., Wada Y., Kokan A., Tanabe K., Goto N., Ohtsu F., Jpn. J. Drug Inform., 22, 7-16 (2020). 